IRENEUSZ NOWAK

Uniwersytet Łódzki

inowak@wpia.uni.lodz.pl

ORCID: 0000-0002-7997-6887

JOANNA WYPORSKA-FRANKIEWICZ

Uniwersytet Łódzki

jwyporska@wpia.uni.lodz.pl

ORCID: 0000-0002-7652-6338

\title{
Biegły skarbowy a wycena majątku zobowiązanego w egzekucji należności podatkowych ${ }^{1}$
}

\section{Treasury expert and an estimation of an obliged person's assets which is delivered in the enforcement of tax claims}

Streszczenie. Przedmiotem artykułu są wybrane kwestie związane z uregulowaną w ustawie o postępowaniu egzekucyjnym w administracji instytucją biegłego skarbowego. Autorzy podkreślają, że biegły skarbowy może sporządzać opinie w zakresie oszacowania majątku zobowiązanego wyłącznie na wniosek organu egzekucyjnego $\mathrm{w}$ ramach prowadzonej procedury egzekucyjnej. W publikacji

1 Tekst powstał we współautorstwie, w równych częściach, a jego koncepcja, metody oraz założenia są wspólnym dziełem autorów. 
postuluje się także wyodrębnienie autonomicznej procedury egzekucyjnej w zakresie należności podatkowoprawnych.

Słowa kluczowe: egzekucja administracyjna; zobowiązany; biegły skarbowy; opinia; podatki.

\begin{abstract}
This article is dedicated to selected issues relating to an institution of a tax expert. This institution is regulated by the Act on enforcement proceedings in the administration. Authors emphasise that a tax expert may prepare opinions in which he/she estimates obligated person's assets only at the request of the enforcement authority. Such a request may be made during the enforcement procedure. Moreover, Authors postulate to establish an autonomous enforcement procedure in the field of tax liabilities.
\end{abstract}

Keywords: administrative execution; an obliged person; tax expert; opinion; taxes.

\title{
1. Uwagi wprowadzające
}

Założeniem niniejszej publikacji jest przedstawienie wybranych zagadnień i problemów związanych z instytucją biegłego skarbowego na gruncie ustawy o postępowaniu egzekucyjnym w administracji ${ }^{2}$. Jednakże zasadniczy cel opracowania odnosi się w szczególności do statusu prawnego biegłego skarbowego oraz jego znaczenia dla zapewnienia ochrony prawnej zobowiązanego (dłużnika, egzekuta) w świetle obowiązujących rozwiązań prawnych i planowanych zmian. Ponadto w artykule zaprezentowane są wnioski dotyczące opinii, w której biegły skarbowy dokonuje wyceny majątku zobowiązanego.

Podjęte w publikacji rozważania uzasadniają postawienie tezy, że ustawa o postępowaniu egzekucyjnym w administracji w kwestii dotyczącej biegłego skarbowego wymaga nowelizacji, co zresztą potwierdzają liczne publikacje naukowe ${ }^{3}$. Wyrażono też zapatrywanie, zgodnie z któ-

2 Ustawa z dnia 17 czerwca 1966 r. o postępowaniu egzekucyjnym w administracji (tekst jedn. Dz.U. z 2019 r. poz. 1438 ze zm.), dalej: u.p.e.a.

3 Zob. w szczególności J. Wyporska-Frankiewicz, Biegły skarbowy a ochrona interesów zobowiqzanego w administracyjnym postępowaniu egzekucyjnym [w:] M. Królikow- 
Biegły skarbowy a wycena majq̨tku...

rym obowiązujący akt prawny w niewystarczający sposób gwarantuje zobowiązanemu ochronę jego praw.

\section{Status prawny biegłego skarbowego}

Zgodnie z definicją legalną z art. 1a pkt 1 u.p.e.a. biegły skarbowy to rzeczoznawca w określonej dziedzinie uprawniony do wyceny majątku zobowiązanego i wpisany na listę biegłych skarbowych prowadzoną przez izbę administracji skarbowej ${ }^{4}$. Prima facie można wywnioskować, że biegły skarbowy to „fachowiec, ekspert” z danej dziedziny, który jest wpisany na listę biegłych skarbowych przez dyrektora izby administracji skarbowej w celu oszacowania majątku zobowiązanego. Jednakże aby prawidłowo ustalić status prawny biegłego skarbowego, należy definicję legalną z art. 1a pkt 1 u.p.e.a. rozpatrywać łącznie z art. 67b-67d u.p.e.a. oraz „posiłkowo” artykułami 95, 96h i 99 u.p.e.a.

Zgodnie z art. 67b u.p.e.a. organ egzekucyjny zwraca się do biegłego skarbowego o oszacowanie wartości zajętej ruchomości ${ }^{5}$ lub prawa mająt-

ska-Olczak (red.), Sektory infrastrukturalne - problematyka prawna, Warszawa 2018, s. 123 i n.

4 Instytucję biegłego skarbowego wprowadziła ustawa z dnia 6 września 2001 r. o zmianie ustawy o postępowaniu egzekucyjnym w administracji oraz niektórych innych ustaw, usuwając przypadki, kiedy organy egzekucyjne zmuszone były, przy wycenie majątku zobowiązanego, do korzystania z usług osób nie zawsze posiadających odpowiednie kwalifikacje - zob. (Dz.U. z 2001 r. Nr 125 poz. 1368); A. Suławko-Karetko, Podmioty administracyjnego postępowania egzekucyjnego [w:] J.P. Tarno (red.), Doradca podatkowy w egzekucji administracyjnej należności pieniężnych, Warszawa 2012, s. 57.

5 Podział rzeczy na rzeczy ruchome i nieruchomości jest podziałem wyczerpującym i zarazem rozłącznym. Oznacza to, że „nie ma więc rzeczy, które nie byłyby albo ruchomościami, albo nieruchomościami. Przy takim dychotomicznym (dwudzielnym) podziale wystarczy określić cechy tylko jednej klasy przedmiotów wchodzących w obręb zakresu dzielonego. Inne przedmioty tego zakresu, niemające tej cechy, z konieczności logicznej wchodzą wówczas do drugiej kategorii. Taką właśnie metodą podziału posłużył się ustawodawca, definiując tylko pojęcie nieruchomości. Wszystkie zatem rzeczy, które nie mają cech nieruchomości, należy zaliczyć do klasy rzeczy ruchomych” - Z. Radwański, A. Olejniczak, Prawo cywilne - część ogólna, Warszawa 2011, s. 114; szerzej Z. Leoński, Administracyjne postępowanie egzekucyjne. Problemy węzłowe, Poznań 2003, s. 38; I. Nowak, Wartość rynkowa nieruchomości jako podstawa opodatkowania w podatku od czynności cywilnoprawnych, „Toruński Rocznik 
kowego ${ }^{6}$. Należy zatem zgodzić się z twierdzeniem, że w art. 67b u.p.e.a. ustawodawca unormował regułę, zgodnie z którą organ egzekucyjny jest co do zasady zobligowany zwracać się do biegłego skarbowego w celu wyceny majątku zobowiązanego ${ }^{7}$.

Biegły skarbowy jest (może być) uczestnikiem biorącym udział w postępowaniu egzekucyjnym w administracji ${ }^{8}$, które prowadzone jest w celu wykonania obowiązków publicznoprawnych wynikających m.in. z indywidualnych aktów podatkowych (decyzji, postanowień), z przepisów materialnego prawa podatkowego (ustaw normujących poszczególne podatki) lub deklaracji podatkowych ${ }^{9}$. Wnioskując a contrario, należy uznać, że biegły skarbowy nie może być pracownikiem organu egzekucyjnego, przez co nie jest umocowany, aby z własnej inicjatywy dysponować władztwem egzekucyjnym w ramach prowadzonego postępowania egzekucyjnego $\mathrm{w}$ administracji ${ }^{10}$. Zwraca na to uwagę również orzecznictwo sądowe, wskazując, że biegły skarbowy dokonujący wyceny przedmiotu zajęcia egzekucyjnego nie jest ani organem egzekucyjnym, ani egzekutorem zatrudnionym przez organ egzekucyjny właściwym do prowadzenia czynności egzekucyjnych ${ }^{11}$.

Podatkowy” 2013/el; tenże Opodatkowanie obrotu nieruchomościami [w:] M. Sęk (red.), Prawo podatkowe. Podręcznik dla Podyplomowego Studium Prawa Podatkowego, t. 3, Łódź 2014, s. 195 i n.

6 Na przykład: z papierów wartościowych niezapisanych na rachunku papierów wartościowych, $\mathrm{z}$ autorskich praw majątkowych i praw pokrewnych, z praw własności przemysłowe oraz z pozostałych praw majątkowych - analogicznie D.R. Kijowski, E. Cisowska-Sakrajda, W. Grześkiewicz, Komentarz do art. 1 a u.p.e.a. [w:] D.R. Kijowski (red.), Ustawa o postępowaniu egzekucyjnym w administracji. Komentarz 2015, Lex/el.

7 R. Suwaj, Komentarz do art. 67 b u.p.e.a., [w:] D.R. Kijowski (red.), Ustawa..., Lex/el.

8 L. Klat-Wertelecka, Egzekucja administracyjna w praktyce, Gdańsk 2013, s. 62-63; M. Szubiakowski, Postępowanie egzekucyjne w administracji [w:] M. Wierzbowski (red.), M. Szubiakowski, A. Wiktorowska, Postępowanie administracyjne - ogólne, podatkowe, egzekucyjne i przed sqdami administracyjnymi, Warszawa 2017, s. 390.

$9 \quad$ M. Masternak, Administracja podatkowe [w:] B. Brzeziński (red.), Prawo podatkowe. Teoria. Instytucje. Funkcjonowania, Toruń 2009, s. 345 i n.

10 P. Przybysz, Administracyjne środki prawne w postępowaniu egzekucyjnym w administracji 2012, Lex/el; P. Ostojski, W. Piątek, Egzekucja administracyjna świadczeń pieniężnych, Wrocław 2014, s. 152 i n.

11 Wyrok WSA w Łodzi z dnia 11 maja 2018 r., III SA/Łd 220/18, Centralna Baza Orzeczeń Sądów Administracyjnych (CBOSA). 
Powołanie biegłego skarbowego może mieć charakter obligatoryjny lub fakultatywny. I tak według art. 99 § 2 u.p.e.a. organ egzekucyjny jest obowiązany powołać biegłego skarbowego w przypadku wniesienia przez zobowiązanego skargi na oszacowanie wartości zajętej ruchomości dokonane przez poborcę skarbowego ${ }^{12}$. Analogicznie, zgodnie z art. $99 \S 3$ u.p.e.a. organ egzekucyjny powołuje biegłego skarbowego w celu oszacowanie wartości zajętych wyrobów użytkowych ze złota, platyny i srebra. Dotyczy to również oszacowania wartości zajętych innych kosztowności, a także maszyn i urządzeń produkcyjnych oraz środków transpor$\mathrm{tu}^{13}$. Także w sytuacji, jeżeli oszacowanie przez poborcę skarbowego wartości zajętych praw nie jest możliwe lub zajęcie jest dokonane przez doręczenie Urzędowi Patentowemu Rzeczypospolitej Polskiej zawiadomienia o zajęciu, organ egzekucyjny zwraca się do biegłego skarbowego o oszacowanie wartości tych praw ${ }^{14}$. Natomiast fakultatywnie organ egzekucyjny może wezwać biegłego skarbowego dla oszacowania wartości wszystkich innych zajętych ruchomości, jeżeli uzna to za potrzebne ${ }^{15}$.

Na pełną aprobatę zasługuje planowana zmiana przepisu art. 99 § 3 u.p.e.a., polegająca na wprowadzeniu katalogu ruchomości, których oszacowanie zastrzeżono do wyłącznej kompetencji biegłego skarbowego. In plus należy także ocenić chęć zastąpienia sformułowania „zajęte wyroby użytkowe ze złota, platyny i srebra” oraz „innej kosztowności” zwrotem „kosztowności”, ponieważ nieuprawnionym jest odwoływanie się do materiału czy kruszcu, z którego została wytworzona zajmowana ruchomość $^{16}$. Można jednak zgłosić wątpliwości co do nowelizacji przepisów związanych z biegłym skarbowym, w myśl której proponuje się zrezygnować z obowiązkowego szacowania przez biegłego skarbowego

12 R. Hauser, A. Skoczylas, Instytucja zażalenia $w$ postępowaniu egzekucyjnym $w$ administracji, www.wuwr.com.pl/online-texts/download/58.html; M. Staniszewski, Egzekucja obowiq̨zków podatkowych 2010, Legalis/el.

13 Analogicznie M. Ofiarska, Egzekucja z ruchomości, Lex/el.

14 Art. 96h § 2 u.p.e.a

15 Art. 99 § 4 u.p.e.a.; M. Masternak, Podmioty biorqce udział w postępowaniu egzekucyjnym [w:] T. Jędrzejewski, M. Masternak, P. Rączka, Administracyjne postępowanie egzekucyjne, Toruń 2013, s. 87.

16 Dotychczasowy katalog nie uwzględniał np. ruchomości z koralu, bursztynu, perły, kamienia szlachetnego itp. 
wartości maszyn, urządzeń produkcyjnych i środków transportu na rzecz pracownika obsługującego organ egzekucyjny. Trudno bowiem podzielić przekonanie „autorów” nowelizacji, że sama analiza znajdujących się w mediach ogłoszeń - a do tego w istocie będą się sprowadzały działania pracowników organu egzekucyjnego - pozwoli na trafne ustalenie potencjalnej wartości rynkowej takich rzeczy, a więc wartości szacunkowej tego typu zajętych ruchomości, bez potrzeby zlecania ich wyceny biegłemu skarbowemu ${ }^{17}$.

\section{3. „Procedura” powoływania biegłego skarbowego}

Uprawnienia do oszacowania wartości ruchomości lub prawa majątkowego zobowiązanego mogą być nadane osobie, która:

1. korzysta w pełni z praw publicznych;

2. posiada:

a) dyplom ukończenia wyższej, średniej lub zasadniczej szkoły o profilu technicznym lub artystycznym lub dyplom mistrza w zawodzie lub kierunku odpowiadającym rodzajowi majątku, którego wartość podlega oszacowaniu,

b) opinię właściwego stowarzyszenia, organizacji zawodowej, szkoły wyższej lub innej instytucji stwierdzającej posiadanie przez tę osobę teoretycznych i praktycznych wiadomości w danej gałęzi techniki, sztuki, rzemiosła, a także innych umiejętności niezbędnych do oszacowania wartości majątku ${ }^{18}$.

Z wnioskiem o nadanie uprawnień do szacowania wartości majątku zobowiązanego kandydat na biegłego skarbowego występuje do dyrektora

17 „Rezygnacja z obowiązku szacowania maszyny, urządzenia produkcyjnego i środka transportu przez biegłego skarbowego nie narusza prawa zobowiązanego do wniesienia skargi na oszacowanie dokonane przez pracownika obsługującego organ egzekucyjny” - uzasadnienie projektu ustawy z dnia 30 stycznia 2019 r. o zmianie ustawy o postępowaniu egzekucyjnym w administracji oraz niektórych innych ustaw, https:/bip.kprm.gov.pl/kpr/form/r9092824586,Projekt-ustawy-o-zmianie-ustawy-opostepowaniu-egzekucyjnym-w-administracji-oraz.html.

Art. 67c $\S 1$ u.p.e.a. 
izby administracji skarbowej ${ }^{19}$. A contrario, organowi egzekucyjnemu z urzędu nie przysługuje inicjatywa w zgłaszaniu kandydatów na biegłych skarbowych. Rozwiązanie takie zasługuje na aprobatę, daje bowiem rękojmie, że kandydat będzie niezależny od organu, co niewątpliwie wpływa na zwiększenie jego niezależności.

Podstawę do podjęcia czynności biegłego skarbowego stanowi wpis kandydata na listę prowadzoną przez izbę administracji skarbowej. Oznacza to, że wpis ma charakter konstytutywny, jeżeli zostanie dokonany przez dyrektora izby administracji skarbowej. W przypadku odmowy dokonania wpisu na listę biegłych skarbowych na postanowienie dyrektora izby administracji skarbowej przysługuje zażalenie, a następnie skarga do sądu administracyjnego ${ }^{20}$.

Biorąc powyższe pod uwagę, należy dostrzec, że wpis kandydata na listę biegłych skarbowych przez dyrektora izby administracji skarbowej ma charakter uznaniowy (świadczy o tym użycie w art. 67c § 1 u.p.e.a. zwrotu uprawnienia „mogą” być nadane). Można jednak mieć wątpliwości co do tego, czy „okolicznością uzasadniającą odmowę wpisu może być np. wpisanie na listę wystarczającej liczby biegłych skarbowych w danej dziedzinie"21. Wydaje się, że brak podstaw prawnych do przyjęcia takiego stanowiska, o ile kandydat spełnia wszystkie przesłanki z art. 67c u.p.e.a. To, że ustawodawca wprowadza uznanie administracyjne, nie oznacza, iż przyzwala na dowolność interpretacyjną ${ }^{22}$. Niestety, prima facie można dostrzec także kolejne ułomności, których dopuścił się ustawodawca, np. w sprawie określenia wzoru listy biegłych skarbowych. W art. 67c § 7

\footnotetext{
Art. 67c § 2 u.p.e.a.

20 Art. 3 § 2 pkt 3 ustawy z dnia 30 sierpnia 2002 r. Prawo o postępowaniu przed sądami administracyjnymi (Dz.U. z 2018 r. poz. 1302 ze zm., dalej: u.p.p.s.a.), zgodnie z którym kontrola działalności administracji publicznej przez sądy administracyjne obejmuje orzekanie w sprawach skarg, m.in. na postanowienia wydane w postępowaniu egzekucyjnym i zabezpieczającym, na które służy zażalenie, z wyłączeniem postanowień wierzyciela o niedopuszczalności zgłoszonego zarzutu oraz postanowień, przedmiotem których jest stanowisko wierzyciela w sprawie zgłoszonego zarzutu.

21 P. Przybysz, Postępowanie egzekucyjne w administracji. Komentarz 2018, Lex/el (komentarz do art. 67c u.p.e.a.).

22 R. Suwaj, Komentarz do art. 67c u.p.e.a..., Lex/el; wyrok NSA z dnia 14 lipca 2017 r., I OSK 1537/16, CBOSA.
} 
u.p.e.a oraz przepisach wykonawczych ${ }^{23}$ wskazał, że lista ma zawierać: liczbę porządkową, datę wpisania na listę, imię i nazwisko, adres zamieszkania, telefon, e-mail, zakres przyznanych uprawnień, wzór uwierzytelnionego podpisu, numer i datę zawiadomienia o wpisaniu na listę oraz datę skreślenia z listy. Natomiast w § 6 art. 67c u.p.e.a. wskazano, że w prowadzonej przez izbę administracji skarbowej liście biegłych skarbowych uwzględnia się tylko: imię i nazwisko biegłego skarbowego i jego adres zamieszkania, zakres przyznanych uprawnień; termin wpisania na listę oraz wzór uwierzytelnionego podpisu biegłego skarbowego ${ }^{24}$. Zatem ustawodawca przy okazji kolejnych nowelizacji powinien uporządkować te kwestie, gdyż mają one znaczenie praktyczne. Tym bardziej że taka zmiana nie będzie przysparzać żadnych problemów, a jedynie uporządkuje przyjęte przez normodawcę rozwiązania.

Lista biegłych skarbowych jest prowadzona według wzoru określonego przez ministra właściwego do spraw finansów publicznych ${ }^{25}$, dostosowanego do techniki informatycznej oraz dostępna dla zainteresowanych w siedzibie odpowiedniej izby administracji skarbowej ${ }^{26}$. Oznacza to, że ustawodawca artykułem 67c $§ 8$ u.p.e.a. wprowadził jawności list biegłych skarbowych. Można jednak zgłosić co do tego rozwiązania pewne wątpliwości, ponieważ właściwszym byłoby, aby w dobie powszechnej już cyfryzacji administracji publicznej takie dane były dostępne w formie elektronicznej na stronach właściwych izb administracji skarbowych. Trudno bowiem podzielić przekonanie ustawodawcy, aby zainteresowane podmioty odwiedzały siedziby izby administracji skarbowej celem zapoznania się z listą biegłych skarbowych. Godzi się jednak wspomnieć, że niektóre izby administracji skarbowej z własnej inicjatywy publikują

23 Zarządzenie nr 24 Ministra Finansów z dnia 16 maja 2014 r. w sprawie określenia wzoru listy biegłych skarbowych (Dz.Urz. Ministra Finansów z 2014 r. poz. 19).

24 Art. 67c § 6 u.p.e.a.

25 W styczniu każdego roku izba administracji skarbowej przekazuje ministrowi właściwemu do spraw finansów publicznych listę biegłych skarbowych, a także zawiadamia niezwłocznie o każdym przypadku wpisania lub wykreślenia z listy biegłego skarbowego - art. 67c § 9 u.p.e.a. 
listy biegłych skarbowych na swoich stronach internetowych ${ }^{27}$ (co należy ocenić zdecydowanie pozytywnie). Wydaje się, że taka informacja powinna się znaleźć w Biuletynie Informacji Publicznej, niemniej z uwagi na to, że z reguły nie jest on jednolicie prowadzony przez poszczególne podmioty, trudno uznać takie rozwiązanie za wystarczające.

Biegłemu skarbowemu za oszacowanie wartości majątku zobowiązanego przysługuje wynagrodzenie zgodne $\mathrm{z}$ zakresem wykonanej pracy w wysokości określonej przez ministra właściwego do spraw finansów publicznych w drodze rozporządzenia. Określając wysokość wynagrodzenia, minister uwzględnia rodzaj i czas pracy oraz wysokość poniesionych przez biegłego skarbowego wydatków związanych z oszacowaniem wartości ruchomości lub prawa majątkowego ${ }^{28}$. Z danych izb administracji skarbowej, które udostępniły na swoich stronach internetowych wykaz biegłych skarbowych, wynika, że przyznane „ekspertom skarbowym” uprawnienia dotyczą co do zasady wyceny (oszacowania): środków transportowych (pojazdów mechanicznych), maszyn i urządzeń (głównie przemysłowych, budowlanych, rolniczych, leśnych), sprzętu elektronicznego i informatycznego, kosztowności i wyrobów jubilerskich, wartości akcji i udziałów spółek prawa handlowego (wycena przedsiębiorstwa), dzieł sztuki i antyków. Rzadziej jest to wycena koni, zegarków, broni i amunicji (rusznikarstwo), produkcji roślinnej, optyki.

\section{Opinia biegłego skarbowego}

Co prawda normodawca nie uregulował formy prawnej, w jakiej organ egzekucyjny powinien zwrócić się do biegłego skarbowego o sporządzenie opinii, jednakże zgodnie z klauzulą generalną z art. 18 u.p.e.a „odpowiedniego” stosowania w postępowaniu egzekucyjnym przepisów Kodek-

27 Tylko 8 z 16 Izb Administracji Skarbowej w Polsce dysponuje elektroniczną listą biegłych skarbowych. Są to IAS w Bydgoszczy, Krakowie, Lublinie, Łodzi, Poznaniu, Szczecinie, Wrocławiu, Zielonej Górze.

28 Art. 67c § 15 u.p.e.a. oraz rozporządzenie Ministra Finansów w sprawie określenia wysokości wynagrodzenia biegłego skarbowego z dnia 20 maja 2014 r. (Dz.U. z 2014 r. poz. 654). 
su postępowania administracyjnego ${ }^{29}$, należy przyjąć, że właściwą formą będzie postanowienie ${ }^{30}$. Bez wątpienia ten indywidualny akt administracyjny może być wydany wyłącznie z urzędu przez organ egzekucyjny ${ }^{31}$, wpływając na przejrzystość prowadzonego postępowania wykonawczego.

Biegły skarbowy jest zdecydowanie dość specyficznym uczestnikiem postępowania egzekucyjnego $^{32}$ i jako sui generis pomocnik (współpracownik) w zakresie dysponowania wiadomościami specjalnymi jest w zasadzie „włączany” do toczącego się procesu z chwilą powołania ${ }^{33}$. A contrario, każdą opinię biegłego wykonaną na zlecenie biernego podmiotu z zakresu egzekucji administracyjnej należy co najwyżej traktować jedynie jako poparcie stanowiska zobowiązanego (dokument prywatny) ${ }^{34}$.

Postanowienie o powołaniu biegłego skarbowego powinno zawierać, oczywiście oprócz podstawowych elementów, m.in. przedmiot i zakres opinii oraz wskazywać termin jej sporządzenia ${ }^{35}$. Wprawdzie termin do złożenia przez biegłego skarbowego „ekspertyzy” w postępowaniu egzekucyjnym w administracji nie jest unormowany, ale stosując odpowiednio przepisy Kodeksu postępowania administracyjnego, opinia powinna być

29 Ustawa z dnia 14 czerwca 1960 r. (tekst jedn. Dz.U. z 2018 r. poz. 2096 ze zm.), dalej:k.p.a.

30 R. Suwaj, Komentarz do art. 67b u.p.e.a..., Lex/el.

31 I. Nowak, Postępowanie administracyjne. Podręcznik akademicki z orzecznictwem, Kielce 2012; B. Adamiak, J. Borkowski, Postępowanie administracyjne i sq̨owoadministracyjne, Warszawa 2017, s. 619 i n.; por. H. Dzwonkowski, Z. Zgierski, Procedury podatkowe, Warszawa 2006, s. 854.

32 Por. P. Dańczak, Inni uczestnicy postępowania administracyjnego [w:] W. Chróścielewski (red.), G. Łaszczyca (red.), A. Matan (red.), System Prawa Administracyjnego Procesowego. Zakres przedmiotowy i podmiotowy postępowania administracyjnego ogólnego, t. II, cz. 1, Warszawa 2018, s. 506 i n.; wyrok WSA w Gliwicach z dnia 20 grudnia 2010 r., I SA/Gl 794/10, CBOSA.

33 Por. W. Chróścielewski, J.P. Tarno, P. Dańczak, Postępowanie administracyjne i postępowanie przed sq̨dami administracyjnymi, Warszawa 2018, s. 163-164; wyrok WSA w Łodzi z dnia 3 sierpnia 2006 r., II SA/Łd 464/06, CBOSA; wyrok NSA z dnia 17 lipca 2008 r., II OSK 884/07, CBOSA; wyrok WSA w Lublinie z dnia 17 grudnia 2014 r., I SA/Lu 642/14, CBOSA; wyrok WSA w Gorzowie Wielkopolskim z dnia 3 listopada 2016 r., I SA/Go 257/16, CBOSA.

34 Por. wyrok WSA w Gorzowie Wielkopolskim z dnia 14 listopada 2013 r., I SA/Go 499/13, CBOSA; wyrok NSA z dnia 25 lutego 2016 r., I FSK 1977/14, CBOSA.

Odpowiednie stosowanie art. 123-126 k.p.a. w związku z art. 18 u.p.e.a. 
złożona przed upływem terminów zakreślonych w art. 35 i nast. k.p.a. ${ }^{36}$. Nie może przy tym ujść uwadze fakt, że czas w toku postępowania egzekucyjnego ma jeszcze większe znaczenie i to nie tylko dla zobowiązanego, ale również dla podmiotów administrujących, które mają przecież za zadanie doprowadzić do przymusowego wykonania obowiązków o charakterze publicznoprawnym. $\mathrm{Z}$ tego też względu termin wyznaczony biegłemu skarbowemu na sporządzenie opinii powinien być skrócony do minimum.

Biegły skarbowy, wydając opinię ${ }^{37}$, używa tytułu biegłego skarbowego z oznaczeniem izby administracji skarbowej, na listę której został wpisany $^{38}$. Oznacza to, że używanie tytułu biegłego skarbowego w innych jego działaniach (poza opiniami na zlecenie podmiotów uprawnionych w postępowaniu egzekucyjnym w administracji) jest bezprawne i dyskredytuje daną osobę w stopniu pozwalającym uznać, że nie daje ona rękojmi należytego wykonywania swoich obowiązków ${ }^{39}$. Zatem biegły skarbowy jako „organ pomocniczy” w przypadkach wymagających wiadomości specjalnych na gruncie ustawy o postępowaniu egzekucyjnym w administracji może używać swojego tytułu wyłącznie sporządzając „ekspertyzę” dla ustalonego w tych przepisach kręgu podmiotów ${ }^{40}$. Tym bardziej biegły skarbowy nie może zlecić sporządzenia opinii innemu podmiotowi (tzw. ekspertyza podzlecona) $)^{41}$.

36 Por. wyrok NSA z dnia 16 czerwca 2000 r., I SA/Lu 367/99, CBOSA; I. Nowak, Terminowość załatwiania spraw przed samorzqdowymi organami podatkowymi (cz. I-II), „Przegląd Podatków Lokalnych i Finansów Samorządowych” 2017, nr 11-12.

37 Opinie noszą czasami miano ekspertyz, zapewne z powodu używania synonimów na określenia biegłego jako znawcy, rzeczoznawcy, czy też eksperta - por. wyrok WSA w Warszawie z dnia 29 marca 2012 r., VI SA/Wa 2341/11, CBOSA.

38 Art. 67c § 13 u.p.e.a.

39 W orzecznictwie przyjmuje się, że jest to całości cech, zdarzeń i okoliczności dotyczących osoby biegłego, składających się na jego wizerunek jako osoby zaufania publicznego - por. wyrok NSA z dnia 11 stycznia 1993 r., II SA 390/92, CBOSA; wyrok WSA w Warszawie z dnia 5 lipca 2007 r., VI SA/Wa 700/07, CBOSA.

40 Por. wyrok NSA z dnia 20 sierpnia 1998 r., II SA 992/98, CBOSA; R. Hauser, A. Skoczylas, Komentarz do art. 67c u.p.e.a. [w:] R. Hauser (red.), A. Skoczylas (red.), Postępowanie egzekucyjne w administracji. Komentarz 2018, Legalis/el.

41 Tamże. 
W ustawie o postępowaniu egzekucyjnym w administracji organ egzekucyjny zawiadamia zobowiązanego o wyznaczonym terminie oszacowania wartości ruchomości lub prawa majątkowego przez biegłego skarbowego i przesyła zobowiązanemu odpis protokołu oszacowania ${ }^{42}$. Oznacza to, że zawiadomienie z art. 67d § 1 u.p.e.a., spełniając wynikające z przepisów standardy legalności ${ }^{43}$, ustanawia gwarancję dla zobowiązanego - organ egzekucyjny musi go bowiem zawiadomićc ${ }^{44}$ o wyznaczonym terminie oszacowania wartości ruchomości lub prawa majątkowego przez biegłego skarbowego i umożliwić mu wzięcie udziału w przeprowadzeniu tej wyceny ${ }^{45}$, a co za tym idzie - przykładowo - może on zadać „ekspertowi” pytania związane ze sporządzaną opinią ${ }^{46}$. Podsumowując powyższe rozważania, należy dostrzec, że udział zobowiązanego podczas oszacowywania jego majątku przez biegłego skarbowego będzie miał materialny wyraz tylko wówczas, gdy zostanie on poinformowany z odpowiednim wyprzedzeniem, tj. minimum 7 dni wcześniej ${ }^{47}$.

Wprawdzie przepisy ustawy o postępowaniu egzekucyjnym w administracji nie normują wymagań, jakim powinna odpowiadać opinia biegłego skarbowego, jednakże zasadne jest uznanie, że oprócz konkluzji musi ona zawierać uzasadnienie zajętego stanowiska ${ }^{48}$. Ponadto, opinia biegłego skarbowego powinna zawierać tzw. modus operandi, tj. opis

\footnotetext{
Art. 67d § 1 u.p.e.a.

Wyrok WSA w Krakowie z dnia 2 kwietnia 2014 r., I SA/Kr 1617/13, CBOSA.

Por. I. Nowak, Istota i znaczenie wezwań w postępowaniu podatkowym, „Przegląd Podatków Lokalnych i Finansów Samorządowych” 2019, nr 7-8, s. 20-26/25-30; tenże Wezwania $w$ świetle pomocy prawnej pomiędzy organami administracji podatkowej na gruncie art. 157 i 157 a Ordynacji podatkowej, „Kwartalnik Prawa Podatkowego” 2018, nr 3, w druku.

Por. R. Kędziora, Kodeks postępowania administracyjnego. Komentarz 2017, Legalis/el.

46 Por. wyrok NSA z dnia 5 kwietnia 2016 r., I GSK 210/16, CBOSA; H. Dzwonkowski, Komentarz do art. 197 o.p., [w:] H. Dzwonkowski (red.), Ordynacja podatkowa. Komentarz 2014, Legalis/el.

47 Art. 79 k.p.a. w związku z art. 18 u.p.e.a. - por. także wyrok WSA we Wrocławiu z dnia 21 lipca 2010 r., I SA/Wr 271/10, CBOSA; wyrok NSA z dnia 27 stycznia 2016 r., II FSK 3293/13, CBOSA; wyrok NSA z dnia 27 stycznia 2016 r., II FSK 3292/13, CBOSA; wyrok WSA w Warszawie z dnia 14 września 2016 r., III SA/Wa 2505/15, CBOSA; A. Mariański, Rozstrzyganie wattpliwości na korzyść podatnika. Zasada prawa podatkowego 2009, Lex/el.

Por. wyrok WSA w Poznaniu z dnia 16 marca 2016 r., IV SA/Po 953/15, CBOSA.
} 
metod i sposobu przeprowadzania badań, określenie porządku, w jakim je dokonano, oraz przytaczać wszystkie argumenty oparte na stwierdzonych okolicznościach, które mają związek z badanymi faktami, a które podbudowane są fachowymi wyjaśnieniami „specjalisty”49. W tym miejscu należy podkreślić, że zasadna byłaby zmiana dotychczasowych przepisów, zgodnie z którą jeżeli opinia biegłego skarbowego jest niepełna lub niejasna albo gdy zachodzi w niej sprzeczność, właściwy organ egzekucyjny mógłby wezwać ponownie takiego biegłego i zażądać od niego złożenia wyjaśnień lub dodatkowej „ekspertyzy”50.

Osoba biegłego skarbowego nie może nasuwać jakichkolwiek podejrzeń co do stronniczości, nierzetelności czy też braku obiektywizmu ${ }^{51}$. Biorąc pod uwagę fakt, że przepisy ustawy o postępowaniu egzekucyjnym w administracji nie regulują kwestii związanych z wyłączeniem biegłych skarbowych, odpowiednie zastosowanie mają przepisy Kodeksu postępowania administracyjnego rozdziału V, pt. Wyłączenie pracownika oraz organu, mieszczące się w dziale I „Przepisy ogólne”. W konsekwencji biegły skarbowy, w stosunku do którego zachodzą przesłanki wyłączenia, nie może sporządzać „ekspertyzy” w danej sprawie ${ }^{52}$.

49 Por. I. Nowak, Status biegłego i jego opinii jako dowodu w jurysdykcyjnym postępowaniu podatkowym (cz. III), „Przegląd Podatków Lokalnych i Finansów Samorządowych” 2018, nr 6, s. 24; wyrok Sądu Apelacyjnego w Łodzi z dnia 25 października 2013 r., I ACa 543/13, Lex nr 1394240.

Por. art. 388 \& 5 projektu ustawy Ordynacja podatkowa z dnia 8 marca 2019 r., https://legislacja.rcl.gov.pl/projekt/12314054/katalog/12523416\#12523416; L. Etel (red.), Nowa Ordynacja podatkowa. Z prac Komisji Kodyfikacyjnej Ogólnego Prawa Podatkowego, Białystok 2017, s. 472-474.

51 Por. I. Nowak, Status biegłego i jego opinii jako dowodu w jurysdykcyjnym postępowaniu podatkowym (cz. II), „Przegląd Podatków Lokalnych i Finansów Samorządowych” 2018, nr 5, s. 19-22; tenże Instytucja wyłączenia organu podatkowego i jego pracowników jako gwarancja bezstronności przy podejmowaniu rozstrzygnięć podatkowych - uwagi krytyczne, „Toruński Rocznik Podatkowy” 2016/el; wyrok WSA w Warszawie z dnia 24 lutego 2006 r., VI SA/Wa 2377/05, CBOSA.

52 Por. W. Chróścielewski, Komentarz do art. 84 k.p.a. [w:] Z. Kmieciak (red.), W. Chróścielewski (red.), Kodeks postępowania administracyjnego. Komentarz 2019, Lex/el; F. Elżanowski, Komentarz do art. 84 k.p.a. [w:] M. Wierzbowski (red.), A. Wiktorowska (red.), Kodeks postępowania administracyjnego. Komentarz 2019, Legalis/el; wyrok NSA z dnia 25 maja 2000 r., I SA/Wr 3014/98, CBOSA. 
Biegły skarbowy może odmówić dokonania szacunku wartości majątku zobowiązanego znajdującego się na terenie działania izby administracji skarbowej, na listę której został wpisany, tylko z ważnych przy$\operatorname{czyn}^{53}$. Oznacza to, że organ egzekucyjny - uznając przyczynę, którą wskazał biegły skarbowy za ważną - powołuje innego biegłego do oszacowania majątku zobowiązanego ${ }^{54}$. Ponadto, zasadna będzie teza, zgodnie z którą dyrektor izby administracji skarbowej, działając na podstawie art. 67c § 10 pkt 2 lit. c) u.p.e.a., uprawniony jest w przypadku stwierdzenia nienależytego wykonywania funkcji biegłego skarbowego do skreślenia go z listy biegłych skarbowych. Wprawdzie „ustawodawca nie definiuje pojęcia nienależytego wykonywania funkcji biegłego skarbowego, jednakże wydaje się, że w grę będą tu wchodziły: nieuzasadniona ważną przyczyną odmowa sporządzenia wyceny; nieuzasadnione, powtarzające się niedochowanie terminu sporządzenia wyceny, odmowa złożenia - na żądanie organu - wyjaśnień w przedmiocie sporządzonej wyceny; niewypełnianie obowiązków przewidzianych przepisami prawa, np. brak zawiadomienia dyrektora izby (administracji - przyp. aut.) skarbowej o zmianie swojego adresu bądź o zamierzonej przerwie w wykonywaniu czynności biegłego skarbowego przez okres dłuższy niż 3 miesiące; zachowania nielicujące $\mathrm{z}$ godnością sprawowanej funkcji, jak np. posługiwanie się tytułem biegłego skarbowego bez związku z faktycznym wykonywaniem czynności biegłego; nierzetelność lub niekompletność sporządzanej wyceny" ${ }^{55}$. Na pełną aprobatę zasługuje konieczność wydania przez dyrektora izby administracji skarbowej postanowienia w tej sprawie oraz fakt, że

53 „Ważna przyczyna”, którą normuje art. 67c § 12 u.p.e.a., in fine jest zwrotem o charakterze nieostrym (klauzulą generalną), co oznacza, że nie jest możliwe stworzenie wyczerpującego katalogu takich sytuacji - P. Borszowski, Określenia nieostre i klauzule generalne w prawie podatkowym 2017, Lex/el; M. Münnich, Nieostre zwroty ocenne w polskim prawie podatkowym, Lublin 2017.

„W obecnym stanie prawnym organ egzekucyjny jest zobowiązany do powołania jednego z biegłych wpisanych na listę biegłych skarbowych, prowadzoną przez izbę administracji skarbowej, chyba że żaden z biegłych z listy nie ma uprawnień do oszacowania wartości zajętych rzeczy lub praw majątkowych. W takiej sytuacji organ egzekucyjny może powołać na biegłego osobę niewpisaną na listę biegłych skarbowych” - P. Przybysz, Postępowanie..., Lex/el, (komentarz do art. 1 a u.p.e.a.).

55 R. Suwaj, Komentarz do art. 67c..., Lex/el. 
biegłemu skarbowemu przysługuje nań zażalenie (art. 67c § 11 u.p.e.a.), a następnie skarga do sądu administracyjnego (art. $3 \S 2$ pkt 3 u.p.p.s.a.).

\section{Możliwość wzruszenia opinii biegłego skarbowego}

W toku administracyjnego postępowania egzekucyjnego organ egzekucyjny podejmuje szereg działań zmierzających w pośredni lub bezpośredni sposób do zrealizowania celu tej procedury, jakim jest zaspokojenie wierzyciela $^{56}$ - a w istocie wykonanie ciążącego na zobowiązanym obowiązku o charakterze publicznoprawnym ${ }^{57}$. Jednakże organ egzekucyjny jest związany oszacowaniem majątku zobowiązanego dokonanym przez biegłego skarbowego, ponieważ „w postępowaniu egzekucyjnym, odmiennie aniżeli w postępowaniu administracyjnym, nie znajduje zastosowania zasada swobodnej oceny dowodów przy korzystaniu przez organ egzekucyjny z wyników szacowania wartości zajętej ruchomości lub prawa majątkowego"58.

Jeżeli zobowiązany nie zgadza się z oszacowaniem przez biegłego skarbowego wartości ruchomości lub prawa majątkowego, może wystąpić do organu egzekucyjnego z wnioskiem o dokonanie tego oszacowania przez biegłego sądowego ${ }^{59}$. W literaturze wskazuje się, że taki „swoisty tryb odwoławczy"60 stanowi dla zobowiązanego gwarancję w postaci ochrony przed skutkami błędnej wyceny jego majątku przez „eksperta” skarbowego $^{61}$ (tzw. środek kontroli prawidłowości pierwotnej wyceny) ${ }^{62}$, ponieważ po pierwsze, wstrzymuje sprzedaż zajętych ruchomości lub

56 Por. wyrok WSA w Gdańsku z dnia 20 marca 2018 r., I SA/Gd 95/18, CBOSA.

57 Por. np. J. Wyporska-Frankiewicz, Gwarancje ochrony zobowiqzanego w egzekucji administracyjnej obowiq̨zków niepieniężnych, Warszawa 2019, s. 83 i n.

58 R. Hauser, Z. Leoński, Komentarz do art. 1 a u.p.e.a..., Legalis/el; P. Ostojski, W. Piątek, Egzekucja..., s. 154; odmiennie R. Suwaj, Uczestnicy postępowania egzekucyjnego [w:] J. Dembczyńska, P. Pietrasz, K. Sobieralski, R. Suwaj, Praktyka administracyjnego postępowania egzekucyjnego, Warszawa 2008, s. 34.

59 Art. 67d § 2 u.p.e.a.

60 Cz. Martysz, Prawa zobowiq̨zanego w postępowaniu egzekucyjnym [w:] J. GlumińskaPawlic (red.), Doradca podatkowy obrońcq praw podatnika, Katowice 2007, s. 54.

61 E. Pierzchała, Środki prawne w postępowaniu egzekucyjnym w administracji 2007, Legalis/el.

62 https://legislacja.rcl.gov.pl/projekt/12321208/katalog/12570816\#12570816. 
prawa majątkowego (tzw. skutek suspensywny) ${ }^{63}$, a po drugie obliguje czynny podmiot w zakresie egzekucji administracyjnej do powołania biegłego sądowego celem weryfikacji opinii wystawionej przez biegłego skarbowego $^{64}$. Jak wskazał A. Skoczylas, instytucja uregulowana w art. 67d § 2 u.p.e.a. jest sui generis ostateczną superekspertyzą ${ }^{65}$ (metaekspertyzą) w zakresie wyceny majątku zobowiązanego. Należy jednak zauważyć, że w literaturze prezentowany jest również pogląd, zgodnie z którym „(...) umożliwienie zobowiązanemu złożenia wniosku o powołanie biegłego skarbowego musi być ocenione jako zupełnie zbędna gwarancja procesowa. Prowadzi ona bowiem do niepotrzebnego przedłużania postępowania oraz generuje niepotrzebne koszty. Przy czym nie ma nic wspólnego z odpowiednim standardem ochrony, który w toku tego postępowania powinien być zobowiązanemu zapewniony. Nie służy bowiem ani do ochrony zobowiązanego przed bezzasadnym, ani przed zbyt daleko idącym zastosowaniem w stosunku do niego środka egzekucyjnego. Równocześnie osłabia sprawne doprowadzenie do przymusowego wykonania ciążącego na zobowiązanym obowiązku"66.

Na uwagę zasługuje planowana nowelizacja art. 67d u.p.e.a., zgodnie z którą zobowiązany może wnieść do organu egzekucyjnego wniosek o dokonanie oszacowania przez biegłego sądowego w terminie 7 dni od dnia doręczenia mu odpisu protokołu oszacowania, o którym mowa w art.67d § 1 u.p.e.a. Wprowadzenie takiego rozwiązania spowoduje jednak, że sens utraci powołanie odrębnej kategorii biegłych do dokonywania szacunku w toku administracyjnego postępowania egzekucyjnego, a co za tym idzie gdyby ustawodawca zdecydowała się na przyjęcie takie-

63 Art. 67d § 4 u.p.e.a.; M. Ofiarska, Egzekucja..., Lex/el.

64 Jeżeli wartość zajętej ruchomości lub prawa majątkowego oszacowana przez biegłego sądowego nie różni się co najmniej o $25 \%$ od wartości oszacowanej przez biegłego skarbowego, koszty oszacowania przez biegłego sądowego ponosi zobowiązany art. 67d § 3 u.p.e.a.; analogicznie J. Wyporska-Frankiewicz, Egzekucja zobowiq̨zań podatkowych [w:] M. Sęk (red.), Prawo podatkowe. Podręcznik dla Podyplomowego Studium Prawa Podatkowego, t. 1, Łódź 2014, s. 484-485.

65 A. Skoczylas, Postępowanie egzekucyjne w administracji [w:] R. Hauser (red.), A. Wróbel (red.), Z. Niewiadomski (red.), Prawo Procesowe Administracyjne. System Prawa Administracyjnego 2017, Legalis/el.

66 J. Wyporska-Frankiewicz, Biegły..., s. 133 i n. 
go rozwiązania, należałoby postulować całkowite zrezygnowanie z kategorii biegłych skarbowych ${ }^{67}$. Należy jednak zauważyć że proponowana zmiana art. 67d u.p.e.a., która sprowadza się do zakreślenia terminu dość krótkiego zresztą - na skuteczne złożenie wniosku o powołanie W sprawie oszacowania biegłego ${ }^{68}$ bez wątpienia zapewni skuteczną egzekucję z zajętego składnika majątkowego na końcowym jego etapie, tj. sprzedaży ${ }^{69}$. Równocześnie zmiana ta nie spowoduje ograniczenia gwarancji ochrony praw zobowiązanego, które w administracyjnym postępowaniu egzekucyjnego powinny być ograniczone ${ }^{70}$. Zasadnym wydaje się nawet, że powinny być one ograniczone do absolutnego minimum w literaturze podkreślano, iż „w toku administracyjnego postępowania egzekucyjnego z uwagi na jego cel, zobowiązanemu powinno przysługiwać jedynie podstawowe kwantum (...) ochrony, które powinno być ograniczone jedynie do instrumentów służących mu do obrony przed bezzasadną lub zbyt daleko idącą, a więc nadmierną egzekucją, przed wyrządzaniem mu nadmiernych dolegliwości” ${ }^{\prime 1}$.

\section{Podsumowanie}

Skuteczność egzekucji obowiązków podatkowych (pieniężnych) w drodze przymusu administracyjnego jest jednym z elementów mających zasadniczy wpływ na „kondycję państwa/samorządu” w zakresie władztwa publicznego ${ }^{72}$.

67 Tamże, s. 133-135.

68 Pod warunkiem, że będzie on dotyczył biegłego skarbowego.

69 W praktyce bardzo często dochodzi do sytuacji, w której „đłłużnik egzekucyjny” celowo składa wniosek tuż przed terminem licytacji majątku, a nawet w tym samym dniu, świadomie przedłużając prowadzoną egzekucję administracyjną.

70 Zob. np. K. Celińska-Grzegorczyk, J. Olszanowski, W. Piątek, A. Skoczylas, Ochrona jednostki a efektywność administracyjnego postępowania egzekucyjnego [w:] T. Jędrzejewski, M. Masternak, P. Rączka (red.), Ochrona praw jednostki w postępowaniu egzekucyjnym w administracji, Toruń 2018, s. 229-250; R. Hauser, Ochrona obywatela w postępowaniu egzekucyjnym w administracji, Poznań 1988, s. 109-110.

71 J. Wyporska-Frankiewicz, Gwarancje..., s. 344-345.

72 Szerzej J. Niczyporuk, S. Fundowicz, J. Radwanowicz (red.), System egzekucji administracyjnej, Warszawa 2004; P. Ostojski, Kilka uwag na temat efektywności polskiej 
W polskim systemie prawnym egzekucja należności podatkowych następuje na podstawie ustawy o postępowaniu egzekucyjnym w administracji $^{73}$. Niestety z dużym sceptycyzmem należy podchodzić do braku ustawowego wyodrębnienia „egzekucji podatkowej”, która byłaby zintegrowana z przepisami prawa podatkowego i uwzględniała specyfikę tejże odrębnej gałęzi prawa ${ }^{74}$. Trudno więc zgodzić się $\mathrm{z}$ ambiwalentną argumentacją autorów projektu Ordynacji podatkowej, jakoby nieujęcie regulacji dotyczących egzekucji należności podatkowych w projekcie Ordynacji podatkowej „nie było (...) dostatecznie uzasadnione na tym etapie porządkowania ogólnego prawa podatkowego. Nie widać przede wszystkim żadnych realnych korzyści z podzielenia obecnej materii ustawy z dnia 17 czerwca 1966 r. o postępowaniu egzekucyjnym w administracji na dwie części, a mianowicie przepisy regulujące egzekucję należności podatkowych oraz przepisy regulujące egzekucję pozostałych należności pieniężnych i obowiązków niepieniężnych. Przeniesienie do ordynacji przepisów dotyczących egzekucji należności podatkowych w żaden sposób nie zwiększy jej efektywności. Poza tym, byłby to kolejny przypadek rozrostu regulacji prawnych i niepotrzebnego dublowania się identycznych przepisów w ordynacji i ustawie o postępowaniu egzekucyjnym. Stanowisko to nie powinno być rozumiane jako postulat pozostawienia bez zmian ustawy o postępowaniu egzekucyjnym w administracji - są one konieczne, ponieważ nierozwiązany pozostaje problem zwiększenia skuteczności egzekwowania należności publicznoprawnych, w tym podatków. Problem ten powinien być jednak rozpatrywany nie tylko w odniesieniu do podatków i nie w ramach prac nad projektem Ordynacji

egzekucji zaległości podatkowych na tle rozwiqzań prawa egzekucyjnego w Szwajcarii, „Toruński Rocznik Podatkowy” 2015/el.

L. Klat-Wertelecka, Niedopuszczalność egzekucji administracyjnej, Wrocław 2009.

74

Por. M. Masternak, Egzekucja podatkowa [w:] L. Etel (red.), System prawa finansowego. Prawo daninowe, Warszawa 2010, s. 809 i n.; tenże Administracja podatkowe [w:] B. Brzeziński (red.), Prawo..., s. 346; I. Nowak, Prawo podatkowe jako prawo publiczne w świetle jego odrębności jako gatęzi prawa - wybrane zagadnienia [w:] P. Ruczkowski (red.), Prawo - społeczeństwo - jednostka. Człowiek - najlepsza inwestycja, Kielce 2010, s, 83-92; zob. również J. Wyporska-Frankiewicz, Gwarancje..., s. 319 in. 
podatkowej”75. Należy odnotować, że w literaturze zwrócono uwagę na to, iż „(...) wobec tak wysokiej i zastanej już w polskich realiach pozycji Ordynacji podatkowej można byłoby rozważań wprowadzenie do niej działu dotyczącego wykonywania obowiązków podatkowych. Stanowiłoby to niejako uzupełnienie tego aktu prawnego, wyeliminowałoby też wszelkie niejasności w tym zakresie. Co więcej, z uwagi na przygotowywaną obecnie nowelizację o.p. zabieg taki byłby dość łatwy do przeprowadzenia. (...)"76.

Obowiązująca ustawa o postępowaniu egzekucyjnym w administracji pomimo licznych nowelizacji, ciągle powoduje liczne trudności w jej stosowaniu, z którym muszą się zmierzyć zarówno organy egzekucyjne, jak i sądy administracyjne, a także zobowiązani (dłużnicy egzekucyjni). Przyczyny tych problemów wynikają m.in. z powodu „niechlujstwa legislacyjnego”, hermetycznego charakteru czy rozbuchanej kazuistyki ${ }^{77}$. Trafny postulat zgłasza W. Chróścielewski, że już najwyższa pora, aby opracować nową ustawę o postępowaniu egzekucyjnym w administracji, ponieważ „granica indolencji ustawodawcy” w tym akcie prawnym została już dawno przekroczona ${ }^{78}$. A co za tym idzie, należy także rozważyć sposób uregulowania procedury egzekucji należności podatkowych, które - jak się wydaje - powinna być ujęta jako autonomiczne postępowanie.

Na tle podniesionych problemów należy jednak pozytywnie ocenić instytucję biegłych skarbowych, którzy jako sui generis „pomocnicy” powoływani przez organ egzekucyjny do służenia wiadomościami specjalnymi, formułują opinie ${ }^{79}$ wyłącznie w postępowaniu egzekucyjnym w administracji. Przy czym przedmiotem opinii „eksperta” skarbowego jest sfera faktów, a nie sfera prawa, oceniana z oznaczonego punktu wi-

https://legislacja.rcl.gov.pl/projekt/12314054/katalog/12523416\#12523416.

J. Wyporska-Frankiewicz, Gwarancje..., s. 319 i n.

77 Szerzej W. Chróścielewski, Przedmiot postępowania egzekucyjnego [w:] W. Chróścielewski, J.P. Tarno, P. Dańczak, Postępowanie..., s. 378.

78 Tamże, s. 378.

79 Por. wyrok WSA w Łodzi z dnia 8 września 2015 r., III SA/Łd 646/15, CBOSA; wyrok WSA w Lublinie z dnia 16 grudnia 2008 r., II SA/Lu 571/08, CBOSA. 
dzenia, tj. specjalistycznej wiedzy ${ }^{80}$. Ponadto przedstawiona przez biegłego skarbowego opinia powinna mieć charakter bezstronny, przez co do „eksperta” skarbowego stosuje się przepisy o wyłączeniu, analogiczne jak wobec pracowników organu administracji publicznej.

Bez wątpienia biegły skarbowy wpisuje się w „formułę” tzw. wolnych zawodów, reglamentowanych administracyjną formą ich powołania $^{81}$. Co więcej, jest to autonomiczna grupa zawodowa, której celem zakreślonym oczywiście przez normodawcę - jest dbałości „o dokonanie możliwie rzetelnej wyceny wartości zajmowanych ruchomości lub praw majątkowych" ${ }^{82}$ zobowiązanego ${ }^{83}$. Nie oznacza to jednak, że dzieło ustawodawcy w tym zakresie można uznać za skończone - wręcz przeciwnie wymaga ono refleksji i zmian, które szczególnie w dobie tworzenia nowej Ordynacji podatkowej wydają się nieuniknione.

\section{Bibliografia:}

Adamiak B., Borkowski J., Postępowanie administracyjne i sq̨dowoadministracyjne, Wolters Kluwer, Warszawa 2017.

Borszowski P., Określenia nieostre i klauzule generalne w prawie podatkowym 2017, Lex/el.

Chróścielewski W., Tarno J.P., Dańczak P., Postępowanie administracyjne i postępowanie przed sqdami administracyjnymi, Wolters Kluwer, Warszawa 2018.

Chróścielewski W., Komentarz do art. 84 k.p.a. [w:] Z. Kmieciak (red.), Chróścielewski W. (red.), Kodeks postępowania administracyjnego. Komentarz 2019, Lex/el.

80 Por. wyrok WSA w Krakowie z dnia 27 stycznia 2010 r., I SA/Kr 1686/09, CBOSA; I. Nowak, Status biegłego i jego opinii jako dowodu w jurysdykcyjnym postępowaniu podatkowym (cz. I), „Przegląd Podatków Lokalnych i Finansów Samorządowych” 2018, nr 4, s. 19 i n.; L. Żukowski, R. Sawuła, Postępowanie administracyjne, Przemyśl-Rzeszów 2012, s. 173.

81 R. Hauser, Z. Leoński, Komentarz do art. 1a u.p.e.a..., Legalis/el.

82 R. Suwaj, Komentarz do art. 67 b u.p.e.a..., Lex/el.

83 Por. I. Nowak, Określenie wartości rynkowej rzeczy i praw majq̨tkowych z uwzględnieniem opinii biegłego w podatkach lokalnych [w:] I. Ramus (red.), Obrót powszechny i gospodarczy. Problemy podatkowoprawne, Toruń 2014, s. 373 i n. 
Celińska-Grzegorczyk K., Olszanowski J., Piątek W., Skoczylas A., Ochrona jednostki a efektywność administracyjnego postępowania egzekucyjnego [w:] T. Jędrzejewski, M. Masternak, P. Rączka (red.), Ochrona praw jednostki w postępowaniu egzekucyjnym w administracji, WNUMK, Toruń 2018.

Dańczak P., Inni uczestnicy postępowania administracyjnego [w:] W. Chróścielewski, G. Łaszczyca, A. Matan (red.), System Prawa Administracyjnego Procesowego. Zakres przedmiotowy i podmiotowy postępowania administracyjnego ogólnego, t. II, cz. 1, Wolters Kluwer, Warszawa 2018.

Dzwonkowski H., Zgierski Z., Procedury podatkowe, Difin, Warszawa 2006.

Dzwonkowski H., Komentarz do art. 197 o.p., [w:] H. Dzwonkowski (red.), Ordynacja podatkowa. Komentarz 2014, Legalis/el.

Elżanowski F., Komentarz do art. 84 k.p.a. [w:] M. Wierzbowski, A. Wiktorowska (red.), Kodeks postępowania administracyjnego. Komentarz 2019, Legalis/el.

Etel L. (red.), Nowa Ordynacja podatkowa. Z prac Komisji Kodyfikacyjnej Ogólnego Prawa Podatkowego, Temida 2, Białystok 2017.

Hauser R., Ochrona obywatela w postępowaniu egzekucyjnym w administracji, WNUAM, Poznań 1988.

Hauser R., Leoński Z., Komentarz do art. 1 a u.p.e.a [w:] R. Hauser, A. Skoczylas (red.), Postępowanie egzekucyjne w administracji. Komentarz 2018, Legalis/el.

Hauser R., Skoczylas A., Instytucja zażalenia w postępowaniu egzekucyjnym w administracji, www.wuwr.com.pl/online-texts/download/58.html.

Hauser R., Skoczylas A., Komentarz do art. 67c u.p.e.a. [w:] Hauser R., Skoczylas A. (red.), Postępowanie egzekucyjne w administracji. Komentarz 2018, Legalis/el.

Jędrzejewski T., Masternak M., Rączka P. (red.), Ochrona praw jednostki w postępowaniu egzekucyjnym w administracji, WNUMK, Toruń 2018.

Kędziora R., Kodeks postępowania administracyjnego. Komentarz 2017, Legalis/el.

Kijowski D.R., Cisowska-Sakrajda E., Grześkiewicz W., Komentarz do art. $1 a$ u.p.e.a. [w:] D.R. Kijowski (red.), Ustawa o postępowaniu egzekucyjnym w administracji. Komentarz 2015, Lex/el.

Klat-Wertelecka L., Niedopuszczalność egzekucji administracyjnej, WUW, Wrocław 2009.

Klat-Wertelecka L., Egzekucja administracyjna w praktyce, ODDK, Gdańsk 2013.

Leoński Z., Administracyjne postępowanie egzekucyjne. Problemy węzłowe, WSB, Poznań 2003.

Mariański A., Rozstrzyganie wątpliwości na korzyść podatnika. Zasada prawa podatkowego 2009, Lex/el. 
Martysz Cz., Prawa zobowiq̨zanego w postępowaniu egzekucyjnym [w:] J. Glumińska-Pawlic (red.), Doradca podatkowy obrońcq praw podatnika, ŚOKIDP, Katowice 2007.

Masternak M., Administracja podatkowe [w:] B. Brzeziński (red.), Prawo podatkowe. Teoria. Instytucje. Funkcjonowania, TNOiK, Toruń 2009.

Masternak M., Egzekucja podatkowa [w:] L. Etel (red.), System prawa finansowego. Prawo daninowe, Wolters Kluwer, Warszawa 2010.

Masternak M., Podmioty biorq̨ce udział $w$ postępowaniu egzekucyjnym [w:] T. Jędrzejewski, M. Masternak, P. Rączka, Administracyjne postępowanie egzekucyjne, TNOiK, Toruń 2013.

Münnich M., Nieostre zwroty ocenne w polskim prawie podatkowym, KUL, Lublin 2017.

Niczyporuk J., Fundowicz S., Radwanowicz J. (red.), System egzekucji administracyjnej, C.H. Beck, Warszawa 2004.

Nowak I., Prawo podatkowe jako prawo publiczne w świetle jego odrębności jako gałęzi prawa - wybrane zagadnienia [w:] P. Ruczkowski (red.), Prawo - społeczeństwo - jednostka. Człowiek - najlepsza inwestycja, WSEiP, Kielce 2010.

Nowak I., Postępowanie administracyjne. Podręcznik akademicki z orzecznictwem, WSEiP, Kielce 2012.

Nowak I., Wartość rynkowa nieruchomości jako podstawa opodatkowania w podatku od czynności cywilnoprawnych, „Toruński Rocznik Podatkowy” 2013/el, s. 137-166.

Nowak I., Opodatkowanie obrotu nieruchomościami [w:] M. Sęk (red.), Prawo podatkowe. Podręcznik dla Podyplomowego Studium Prawa Podatkowego, t. 3, UŁ, Łódź 2014.

Nowak I., Określenie wartości rynkowej rzeczy i praw majq̨tkowych z uwzględnieniem opinii biegłego w podatkach lokalnych [w:] I. Ramus (red.), Obrót powszechny i gospodarczy. Problemy podatkowoprawne, Adam Marszałek, Toruń 2014.

Nowak I., Instytucja wyłączenia organu podatkowego i jego pracowników jako gwarancja bezstronności przy podejmowaniu rozstrzygnięć podatkowych uwagi krytyczne, „Toruński Rocznik Podatkowy” 2016/el, s. 70-86.

Nowak I., Terminowość załatwiania spraw przed samorzq̨dowymi organami podatkowymi (cz. I-II), „Przegląd Podatków Lokalnych i Finansów Samorządowych” 2017, nr 11-12, s. 18-26/21-28. 
Nowak I., Wezwania $w$ świetle pomocy prawnej pomiędzy organami administracji podatkowej na gruncie art. 157 i 157a Ordynacji podatkowej, „Kwartalnik Prawa Podatkowego" 2018, nr 3, w druku.

Nowak I., Status biegłego i jego opinii jako dowodu w jurysdykcyjnym postępowaniu podatkowym (cz. I), „Przegląd Podatków Lokalnych i Finansów Samorządowych” 2018, nr 4, s. 19-26.

Nowak I., Status biegłego i jego opinii jako dowodu w jurysdykcyjnym postępowaniu podatkowym (cz. II), „Przegląd Podatków Lokalnych i Finansów Samorządowych” 2018, nr 5, s. 19-27.

Nowak I., Status biegłego i jego opinii jako dowodu w jurysdykcyjnym postępowaniu podatkowym (cz. III), „Przegląd Podatków Lokalnych i Finansów Samorządowych” 2018, nr 6, s. 23-29.

Nowak I., Istota i znaczenie wezwań w postępowaniu podatkowym, „Przegląd Podatków Lokalnych i Finansów Samorządowych” 2019, nr 7-8, s. 20-26/25-30.

Ofiarska M., Egzekucja z ruchomości, Lex/el.

Ostojski P., Piątek W., Egzekucja administracyjna świadczeń pieniężnych, Presscom, Wrocław 2014.

Ostojski P., Kilka uwag na temat efektywności polskiej egzekucji zaległości podatkowych na tle rozwiqzań prawa egzekucyjnego w Szwajcarii, „Toruński Rocznik Podatkowy” 2015/el, s. 82-97.

Pierzchała E., Środki prawne $w$ postępowaniu egzekucyjnym $w$ administracji 2007, Legalis/el.

Przybysz P., Administracyjne środki prawne $w$ postępowaniu egzekucyjnym w administracji 2012, Lex/el.

Przybysz P., Postępowanie egzekucyjne w administracji. Komentarz 2018, Lex/el (komentarz do art. 67c u.p.e.a.).

Radwański Z., Olejniczak A., Prawo cywilne - część ogólna, C.H. Beck, Warszawa 2011.

Skoczylas A., Postępowanie egzekucyjne w administracji [w:] R. Hauser, A. Wróbel, Z. Niewiadomski (red.), Prawo Procesowe Administracyjne. System Prawa Administracyjnego 2017, Legalis/el.

Staniszewski M., Egzekucja obowiq̨zków podatkowych 2010, Legalis/el.

Suławko-Karetko A., Podmioty administracyjnego postępowania egzekucyjnego [w:] J.P. Tarno (red.), Doradca podatkowy w egzekucji administracyjnej należności pieniężnych, Wolters Kluwer, Warszawa 2012. 
Suwaj R., Uczestnicy postępowania egzekucyjnego [w:] J. Dembczyńska, P. Pietrasz, K. Sobieralski, R. Suwaj, Praktyka administracyjnego postępowania egzekucyjnego, Presscom, Warszawa 2008.

Suwaj R., Komentarz do art. 67 b u.p.e.a. [w:] D.R. Kijowski (red.), Ustawa o postępowaniu egzekucyjnym w administracji. Komentarz 2015, Lex/el.

Suwaj R., Komentarz do art. 67c u.p.e.a. [w:] D.R. Kijowski (red.), Ustawa o postępowaniu egzekucyjnym $w$ administracji. Komentarz 2015, Lex/el.

Szubiakowski M., Postępowanie egzekucyjne w administracji [w:] M. Wierzbowski (red.), M. Szubiakowski, A. Wiktorowska, Postępowanie administracyjne - ogólne, podatkowe, egzekucyjne i przed sqdami administracyjnymi, C.H. Beck, Warszawa 2017.

Wyporska-Frankiewicz J., Egzekucja zobowiq̨zań podatkowych [w:] M. Sęk (red.), Prawo podatkowe. Podręcznik dla Podyplomowego Studium Prawa Podatkowego, t. 1, UŁ, Łódź 2014.

Wyporska-Frankiewicz J., Gwarancje ochrony zobowiqzanego w egzekucji administracyjnej obowiq̨zków niepieniężnych, Wolters Kluwer, Warszawa 2019.

Wyporska-Frankiewicz J., Biegły skarbowy a ochrona interesów zobowiqzanego $w$ administracyjnym postępowaniu egzekucyjnym [w:] M. Królikowska-Olczak (red.), Sektory infrastrukturalne - problematyka prawna, C.H. Beck, Warszawa 2018.

Żukowski L., Sawuła R., Postępowanie administracyjne, WSPAP-R, PrzemyślRzeszów 2012. 